\title{
EFFECT OF STORAGE CONDITIONS ON BIOLOGICALLY ACTIVE COMPOUNDS IN PURPLE-FLESHED POTATOES
}

\author{
Reinis Zariṇš ${ }^{1, \#}$, Zanda Krūma1, and Ilze Skrabule² \\ ${ }^{1}$ Faculty of Food Technology, Latvia University of Life Sciences and Technologies, 22 Rĩgas Str., Jelgava, LV-3004, LATVIA \\ ${ }^{2}$ Institute of Agricultural Resources and Economics, 2 Zinātnes Str., Priekuḷi, Priekuḷi Parish, Cēsis Municipality, LV- 4126, LATVIA \\ \# Corresponding author, reinis-zarins@inbox.Iv
}

Communicated by Tatjana Ķince

\begin{abstract}
Potatoes (Solanum tuberosum L.) are an important crop. They are a source of natural phenolic compounds with high biological activity. Stress factors may decrease phenolic concentration and increase concentration of the toxin glycoalkaloid as a result of plant self-protection against stress. The aim of the current study was to evaluate the effect of storage under light on the concentration of biologically active compounds in purple-fleshed potatoes. The purple-fleshed potato variety 'Blue Congo' was harvested from test fields of the Institute of Agricultural Resources and Economics in Latvia. Storage under light was performed in a climate chamber ICH110 (Memmert $\mathrm{GmbH}+\mathrm{Co} . \mathrm{KG}$, Germany) with constant pre-set relative air humidity $85 \%$, temperature $+22{ }^{\circ} \mathrm{C}$, and full-spectrum light (Eecoo, 1200 W, LED) intensity of 2000 lux and total time seven days. Total phenolic concentration, antioxidant activity and total glycoalkaloid concentration was measured using spectrophotometry, and moisture was determined according to standard LVS 272:2000. Storage under artificial light of purple-fleshed variety 'Blue Congo' potatoes caused decrease of total phenolic concentration and antioxidant activity, no change in moisture level, and increase of total glycoalkaloid concentration.
\end{abstract}

Keywords: Blue Congo potatoes, phenolic compounds, glycoalkaloids, antioxidant activity, storage under light.

\section{INTRODUCTION}

Nowadays there is a growing trend in the use of food with higher levels of natural antioxidants (Kumar et al., 2015). Potato (Solanum tuberosum L.) production has increased tremendously in developing countries in the past two decades (Paul et al., 2012). They are rich in phenolics, a biologically active compound that has proven positive influence on human wellbeing (Akyol et al., 2016), and are source of phenolic compounds. They are ranked as the third consumed crop (Paul et al., 2012). Phenolic compounds have antioxidant, antibacterial, anticarcinogenic, anti-inflammatory, antiglycemic, antiviral, and vasodilatory effects (Berghe, 2012; Kazeem et al., 2012; Konaté et al., 2012), and a positive effect on human longevity, ocular organs, mental health, and the cardiovascular system (Manach et al., 2004; Scalbert et al., 2005). Positive correlation between phenolic concentration and total antioxidant activity in potatoes has been found (Andre et al., 2007). Phenolics are found in the whole tuber, but the peels have highest saturation of phenolics (Lewis et al., 1999; Nara et al., 2006). They are present in all potato varieties, but the phenolic amount almost double in purple-fleshed (also redfleshed) varieties compared to white-fleshed and yellowfleshed varieties (Ezekiel et al., 2013). This difference in the amount of phenolic compounds might be explained by anthocyanins, which are the main colour pigments in purple-fleshed potatoes (Im et al., 2008; Al-Weshahy and Rao, 2009).

In addition to nutritional compounds, potatoes contain also glycoalkaloids, which are natural toxins. Glycoalkaloid build-up is caused by natural and human caused stress factors (Papathanasiou et al., 1999). The major glycoalkaloids in potatoes are $\alpha$-solanine and $\alpha$-chaconine (Friedman, Levin, 2009; Omayio et al., 2016). The World Health Organisation reported that the safe level of glycoalkaloids in fresh potato tubers is from 20 to $100 \mathrm{mg} \cdot \mathrm{kg}^{-1}$ (Evaluation of 
Certain..., 1992). Other studies have shown that concentration of even up to $200 \mathrm{mg} \cdot \mathrm{kg}^{-1}$ glycoalkaloid in fresh potatoes is safe (Karim et al., 1997; Jansky, 2010). Glycoalkaloid intoxication can lead to digestive illnesses, diarrhoea, and vomiting (Hellenas et al., 1992), and higher doses might result in nerve system damage, coma and even death (Langkildea et al., 2009).

Studies have shown that artificial light can accelerate development of glycoalkaloids (Dale et al., 1993; Machado et al., 2007) and also might increase the level of phenolic compounds and antioxidant activity (Nascimento et al., 2013; Ballester and Lafuente, 2017).

Inappropriate storage might lead to increased toxicity (glycoalcoloids) and/or lower levels of valuable compounds (phenolics), and more study of these relationships is required. Regulated temperature and light precision can be maintained only in artificial experimental conditions that replicate specific natural conditions, which are needed to understand biochemical changes in potatoes under specific conditions.

The aim of the current study was to evaluate the effect of the storage under artificial light on levels of biologically active compounds in purple-fleshed potatoes.

\section{MATERIALS AND METHODS}

The raw material used was a harvest crop of purple-flesh potato variety 'Blue Congo', harvested from test fields of the Institute of Agricultural Resources and Economics, Latvia. Storage before treatment was with light at $+4{ }^{\circ} \mathrm{C}$ temperature and $80 \pm 5 \%$ relative air humidity. Treatment was storage for seven days in a climate chamber ICH110 (Memmert $\mathrm{GmbH}+\mathrm{Co}$. KG, Germany) with constant and even pre-set relative air humidity $85 \%$, temperature $+22{ }^{\circ} \mathrm{C}$, and full-spectrum light (Eecoo, $1200 \mathrm{~W}$, LED) intensity of 2000 lux. This period was suggested in literature to represent real situations when potatoes are shortly marketed/ stored on shop shelves.

Chemical analysis. Total phenolic concentration was determined using the Folin-Ciocalteu spectrophotometric method (Singleton et al., 1999) with ethanol as a solvent. Absorbance was measured at $765 \mathrm{~nm}$ and total phenol concentration was expressed as gallic acid equivalents per $100 \mathrm{~g}^{-1}$ dry weight of plant material. Antioxidant activity was estimated on the basis of scavenging activity using the stable 2,2-diphenyl-1-picrylhydraziyl (DPPH') radical and 2,2'-azinobis(3-ethylbenz-thiazoline-6-sulfonic) acid (ABTS'+) radical cation assay. Antioxidant activity was expressed as TE $.100 \mathrm{~g}^{-1}$ of plant material. Moisture content was determined according to LVS 272:2000 using an EBC 4.2. Incubator, "Memmert, model 100-800". Total glycoalkaloid concentration was measured according to method modified by Skrabule et al. (2010).

Statistical analysis. Mathematical processing and interpretation of data was done in MS-Excel, SPSS 22.0 using analysis of variance $(p<0.05)$ and correlation analysis $(p<$ $0.05)$. Data represent means \pm standard deviation $(n=6)$.

\section{RESULTS}

Total phenolics. The total phenolic concentration of the studied potato flesh ranged from $313.66 \mathrm{mg} \cdot 100 \mathrm{~g}^{-1}$ before treatment with light to $237.37 \mathrm{mg} \cdot 100 \mathrm{~g}^{-1}$ fresh weight after treatment with light on day 7 (Fig. 1). There was a rapid decrease to $241.36 \mathrm{mg} \cdot 100 \mathrm{~g}^{-1}$ after 3-day treatment and no significant differences on day 7 compared to third day. The phenolic concentration of potato peels ranged from 306.51 $\mathrm{mg} \cdot 100 \mathrm{~g}^{-1}$ before treatment with light to $313.89 \mathrm{mg} \cdot 100 \mathrm{~g}^{-1}$ after treatment with light on day 7 , and despite a slight decrease $\left(287.83 \mathrm{mg} \cdot 100 \mathrm{~g}^{-1}\right)$ of phenolic concentration on day 3 , it increased and even exceeded initial total phenolic concentration on day 7 .

Artificial lighting during relatively short term storage had non-significant effect on total phenolic concentration in potato peels, while the concentration in flesh showed a rapid decrease in first three days followed by stable and steady decrease during the longer period. Seven days is a considerable period that is based on real-life situations when potatoes are stored in shop shelves and are exposed to increased stress factors (high temperature/light).

DPPH scavenging activity. 2,2-diphenyl-1-picrylhydrazyl (DPPH) scavenging activity of potato flesh ranged from $13.60 \mathrm{mg} \cdot 100 \mathrm{~g}^{-1}$ before treatment with light to 10.46 $\mathrm{mg} \cdot 100 \mathrm{~g}^{-1}$ after treatment with light on day 7 (Fig. 2). There was a decrease $\left(11.01 \mathrm{mg} \cdot 100 \mathrm{~g}^{-1}\right)$ after 3-day treatment and no significant difference on day 7 compared to the third day. The DPPH scavenging activity of potato peels ranged from $17.96 \mathrm{mg} \cdot 100 \mathrm{~g}^{-1}$ before treatment with light to $17.82 \mathrm{mg} \cdot 100 \mathrm{~g}^{-1}$ after treatment with light on day 7 . There was a slight decrease $\left(16.14 \mathrm{mg} \cdot 100 \mathrm{~g}^{-1}\right)$ on day 3 , which then increased and on day 7 almost reached the initial DPPH scavenging activity.

While a slight decrease of DPPH scavenging activity during seven day storage under light was found for potato flesh, potato peels during same period showed stronger ability to

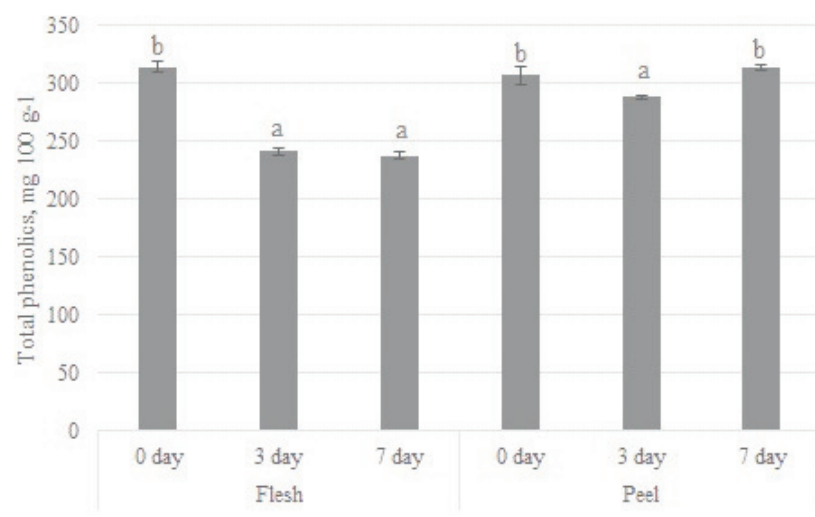

Fig. 1. Total phenolic concentration of potato flesh and peel. Values with different letters are significantly different $(p<0.05)$ based on the Tukey's test. 


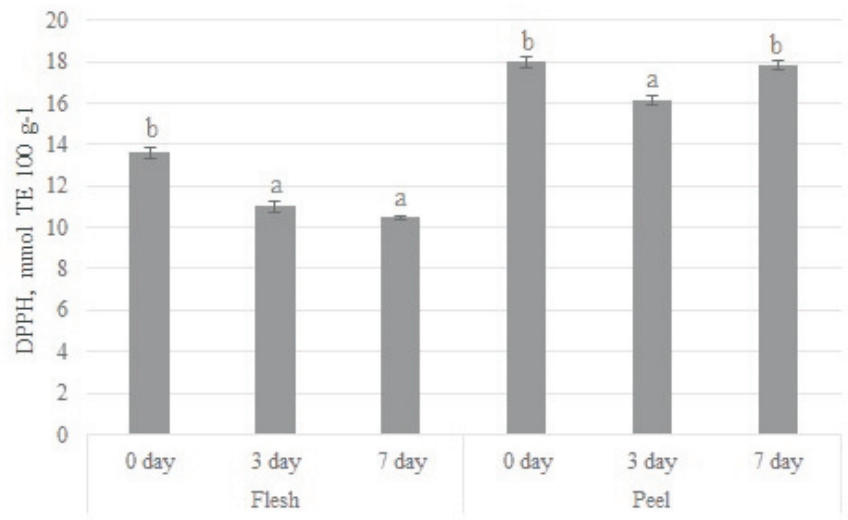

Fig. 2. DPPH scavenging activity of potato flesh and peel. Values with different letters are significantly different $(p<0.05)$ based on the Tukey's test.

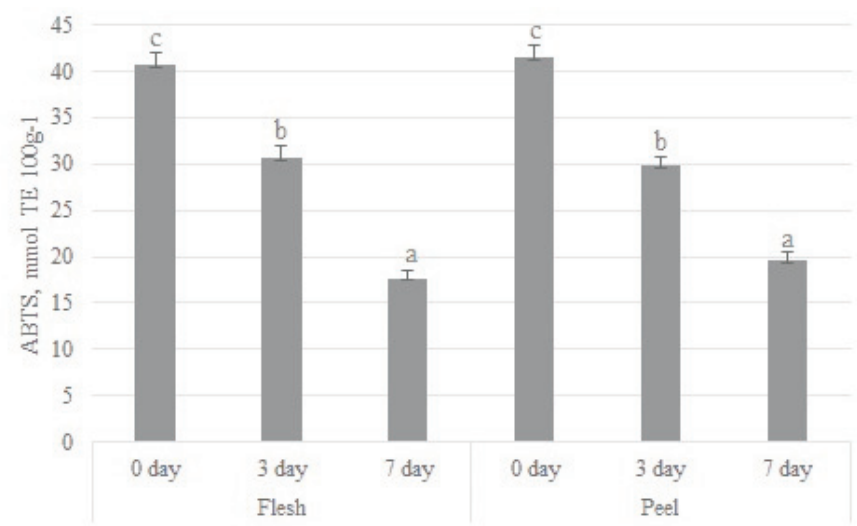

Fig. 3. ABTS scavenging activity of potato flesh and peel. Values with different letters are significantly different $(p<0.05)$ based on the Tukey's test.

preserve DPPH scavenging activity. The data suggest that storage under artificial lighting generally has only a slight effect on potato DPPH scavenging activity, at least during a relatively short period of time.

ABTS scavenging activity. 2,2'-azino-bis(3-ethylbenzothiazoline-6-sulphonic acid) (ABTS) scavenging activity of potato flesh ranged from $40.78 \mathrm{mg} \cdot 100 \mathrm{~g}^{-1}$ before treatment with light to $17.66 \mathrm{mg} \cdot 100 \mathrm{~g}^{-1}$ after treatment with light on day 7 (Fig. 3). There was a rapid decrease (30.69 mg.100 $\mathrm{g}^{-1}$ ) after 3-day treatment and another rapid decrease on day 7. ABTS scavenging activity of potato peels ranged from $41.56 \mathrm{mg} \cdot 100 \mathrm{~g}^{-1}$ before treatment with light to 19.57 $\mathrm{mg} \cdot 100 \mathrm{~g}^{-1}$ after treatment with light on day 7 , and there was a quite rapid decrease $\left(29.81 \mathrm{mg} \cdot 100 \mathrm{~g}^{-1}\right)$ on day 3 followed by another rapid decrease on day 7 .

The study showed that ABTS scavenging activity significantly decreased during storage under light in the seven-day period. The data suggests that longer storage might lead to a greater and more rapid decrease.

Total glycoalkaloid content. The total glycoalkaloid concentration of potato flesh ranged from $1.18 \mathrm{mg} \cdot 100 \mathrm{~g}^{-1}$ before treatment with light to $1.72 \mathrm{mg} \cdot 100 \mathrm{~g}^{-1}$ after treatment

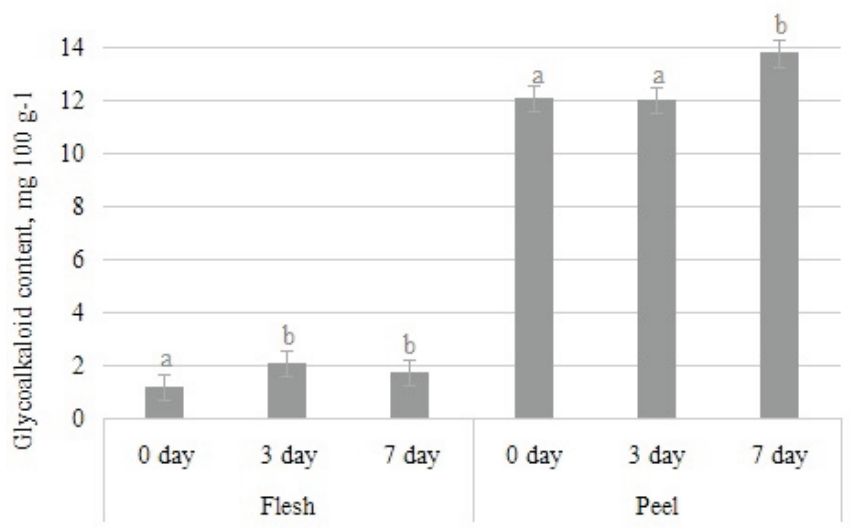

Fig. 4. Total glycoalkaloid concentration of potato flesh and peel. Values with different letters are significantly different $(p<0.05)$ based on the Tukey's test.

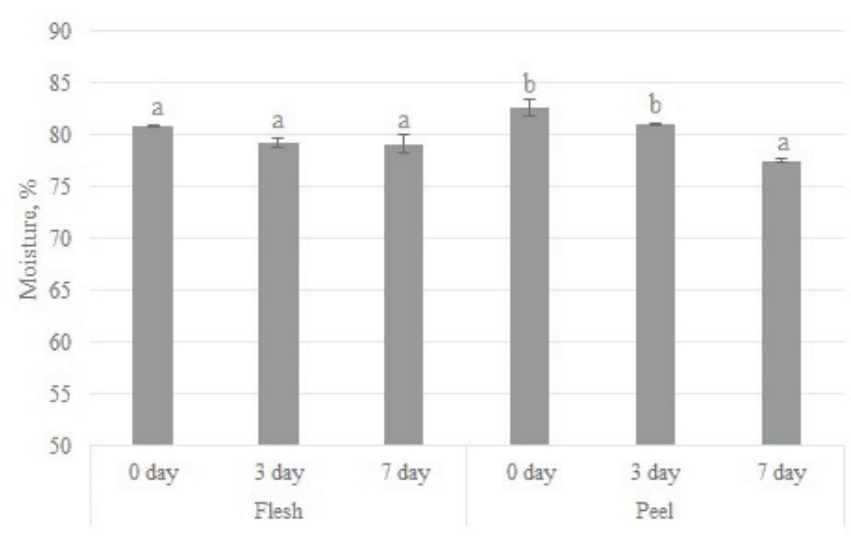

Fig. 5. Moisture of potato flesh and peel. Values with different letters are significantly different $(p<0.05)$ based on the Tukey's test.

with light on day 7 (Fig. 4) with a rapid increase (almost double) (2.06 mg.100 g $\left.\mathrm{g}^{-1}\right)$ after 3 day treatment and no significant difference on day 7 compared to third day. The glycoalkaloid concentration of potato peels ranged from 12.09 $\mathrm{mg} \cdot 100 \mathrm{~g}^{-1}$ before treatment with light to $13.81 \mathrm{~m} \cdot 100 \mathrm{~g}^{-1}$ after treatment with light on day 7 , showing no significant changes during the first three days $\left(12.04 \mathrm{mg} \cdot 100 \mathrm{~g}^{-1}\right.$ after three-day treatment), but which was followed by rapid increase of concentration.

Moisture. Moisture of potato flesh ranged from $80.83 \%$ before treatment with light to $79.12 \%$ after treatment with light on day 7 (Fig. 5), with a slight decrease (79.23\%) after 3 -day treatment and another slight decrease on day 7 . The moisture of potato peels ranged from $82.60 \%$ before treatment with light to $77.51 \%$ after treatment with light on day 7. Only a slight decrease $(81.00 \%)$ of moisture was observed on day 3 followed by another slight decrease on day 7.

The experiment showed that purple-fleshed potato retained moisture content under artificial lighting storage conditions. Longer exposure to light and longer storage time would show further decrease of moisture, but based on the study data, the decrease could be slow and without rapid changes. 


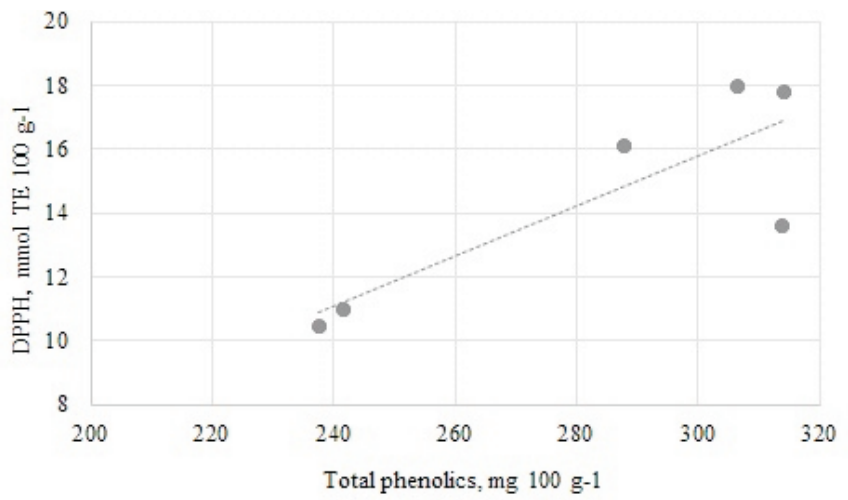

Fig. 6. Correlation between total phenolic concentration and DPPH scavenging activity of potato.

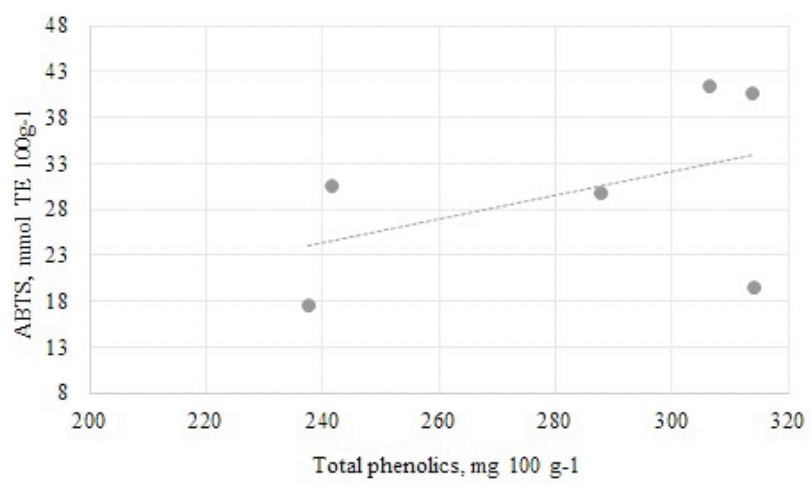

Fig. 7. Correlation between total phenolic concentration and ABTS scavenging activity of potato.

The effect of moisture content change on levels of biocompounds was insignificant.

Correlation. Previous studies suggest that there is a strong positive correlation between phenolic concentration and antioxidant capacity (Andre et al., 2007).

The current study showed strong positive correlation (coefficient: 0.84) between total phenolic concentration and DPPH scavenging activity (Fig. 6) and that a change in one of these parameter will trigger change of the other.

Correlation between ABTS scavenging activity and total phenolic concentration (Fig. 7) was moderate positive (coefficient: 0.45 ).

Correlation between ABTS scavenging activity and DPPH scavenging activity (Fig. 8) was weak positive (coefficient: $0.25)$.

Correlation between total glycoalkaloid concentration and total phenolic concentration (Fig. 9) of potato was moderate positive (coefficient: 0.57 ).

Correlation between total glycoalkaloid concentration and DPPH scavenging activity (Fig. 10) was strong positive (coefficient: 0.92)

There was no correlation between total glycoalkaloid concentration and ABTS scavenging activity.

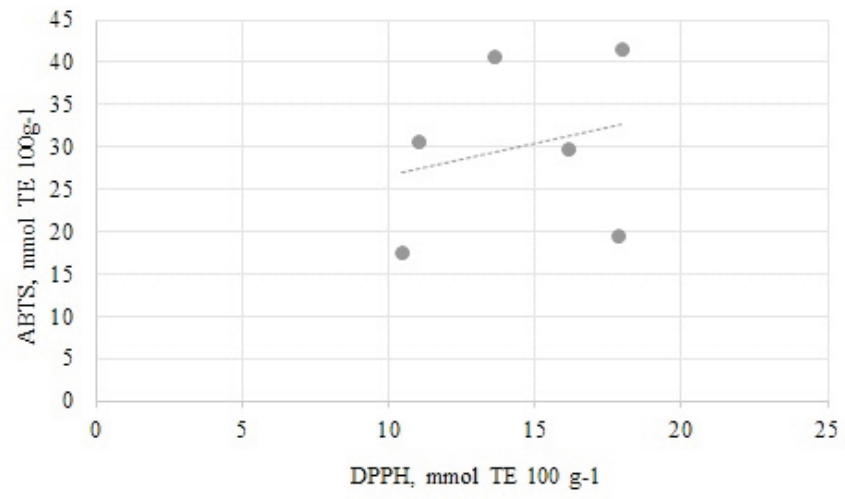

Fig. 8. Correlation between DPPH scavenging activity and ABTS scavenging activity of potato.

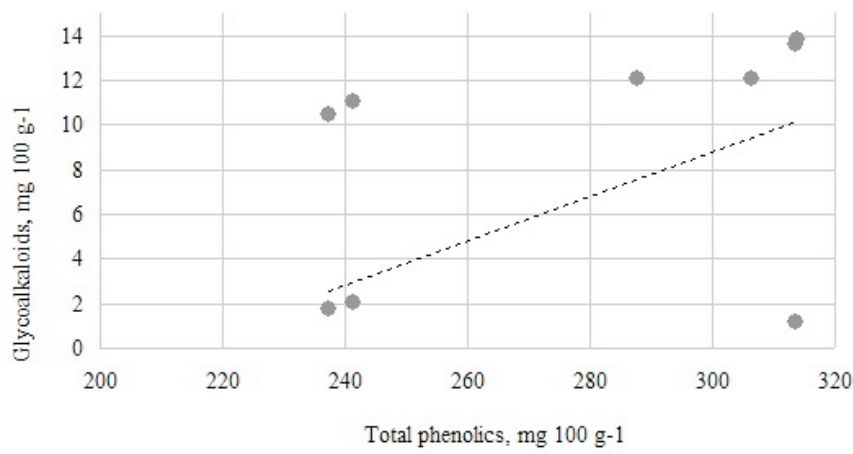

Fig. 9. Correlation between total phenolic concentration and total glycoalkaloid concentration of potato.

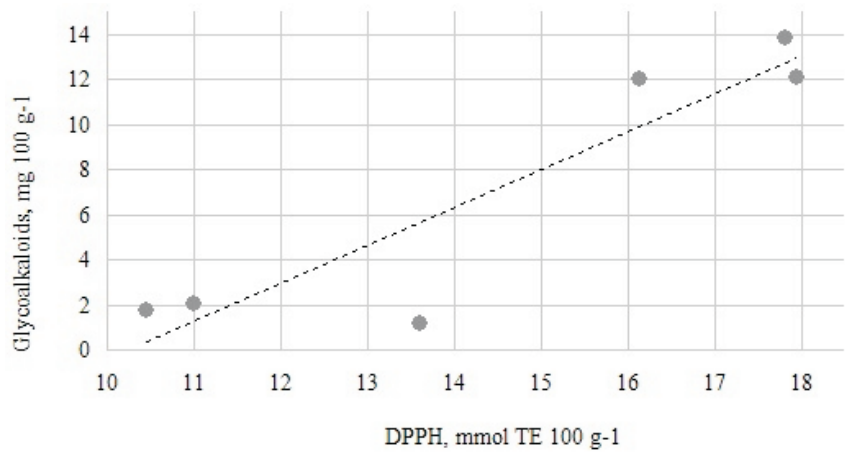

Fig. 10. Correlation between DPPH scavenging activity and total glycoalkaloid concentration of potato.

\section{DISCUSSION}

In the current study, full-spectrum light was used as an artificial light source. Such light imitates sunlight (negative factor during potato harvest) and covers the light spectrum existing on shop shelves and in storage facilities (usually uses fluorescent light bulbs, which is a negative factor during potato short-term and long-term storage). The temperature and light intensity level that was used in the study was based on mean temperature and light measured in thirty shops in Latvia.

Antioxidant activity (scavenging activity of an extract) is the ability of redox molecules in potatoes to suppress free 
radicals (Puchau et al., 2010) such as DPPH and ABTS, and that ability is closely linked to total phenolic concentration (Leo et al., 2008). Studies have shown that light has negative influence on the anti-oxidative profile of potato (Chellaram at al., 2014). The current study confirms these studies, as storage under light caused decreased total phenolic concentration and DPPH scavenging activity in potato flesh. In peels, both of these parameters decreased after the third day and returned to the initial level on the seventh day. There was a drastic drop in ABTS scavenging activity during the seven-day storage period in both flesh and peels. This shows that, compared to DPPH scavenging activity, ABTS scavenging activity (antioxidant activity) suffers (decreases) the most from storage artificial light. The present study thus showed that bright light and high temperature as stress factors negatively affected antioxidant activity. Phenolics as bio-active compounds are directly linked to antioxidant activity (ABTS and DPPH scavenging activity) of potatoes. When phenolic concentration decreases, antioxidant (scavenging) activity also decreases. It cannot be excluded that there are also other compounds that are directly or indirectly linked to antioxidant (scavenging) activity in potatoes. This study was focused on the most widely known compounds: phenolics and toxic glycoalkaloids with antioxidant (scavenging) activity.

Previous studies have shown that artificial light might promote glycoalkaloid development (Dale et al., 1993; Machado et al., 2007). The present study also found that total glycoalkaloid concentration in potatoes flesh increased, almost doubling, during the first three days of storage under light, but there were no significant differences on seventh day compared to the third day. In potato peels there was no significant change in total glycoalkaloid concentration during the first three days, but in the period from day three to seven there was a rapid increase.

In the storage experiment, purple-fleshed potato had the ability to retain moisture to a large extent in artificial lighting storage conditions. However, longer exposure to light and storage might result in decrease of moisture, based on current study data, the decrease could be slow and without rapid changes.

\section{ACKNOWLEDGEMENTS}

The present research was supported by the programme "Strengthening Research Capacity in the Latvia University of Agriculture" project "Effect of Storage Conditions and Processing Technology on Dynamics of Secondary Metabolites in Potatoes Tubers" (Z16).

\section{REFERENCES}

Akyol, H., Riciputi, Y., Capanoglu, E., Caboni, M. F., Verardo, V. (2016). Phenolic compounds in the potato and its byproducts: An overview. Int. J. Mol. Sci., 17 (6), 835, 1-19.

Al-Weshahy, A., Rao, V. A. (2009). Isolation and characterization of functional components from peel samples of six potatoes varieties growing in Ontario. Food Res. Int., 42 (8), 1062-1066.
Andre, C. M., Ghislain, M., Bertin, P., Oufir, M., Herrera, M. R., Hoffmann, L., Hausman, J. F., Larondelle, Y., Evers, D. (2007). Andean potato cultivars (Solanum tuberosum L.) as a source of antioxidant and mineral micronutrients. J. Agricult. Food Chem., 55 (2), 366-378.

Ballester, A. R., Lafuente, M. T. (2017). LED blue light-induced changes in phenolics and ethylene in citrus fruit: Implication in elicited resistance against Penicillium digitatum infection. Food Chem., 218, 575-583.

Berghe, W. V. (2012). Epigenetic impact of dietary polyphenols in cancer chemoprevention: Lifelong remodeling of our epigenomes. Pharmac. Res. $\mathbf{6 5}(6), 565-576$

Birch, P. R. J., Bryan, G., Fenton, B., Gilroy, E. M., Hein, I., Jones, J. T., Prashar A., Taylor, M. A., Torrance, L., Toth, I. K. (2012). Crops that feed the world: Potato - are the trends of increased global production sustainable. Food Security, 4, 477-508.

Dale, M. F. B., Grfiffiths, D. W., Bain, H., Todd, D. (1993). Glycoalkaloid increase in Solanum tuberosum on exposure to light. Ann. Appl. Biol., 123, $411-418$.

Ezekiel, R., Singh, N., Sharma, S., Kaur, A. (2013). Beneficial phytochemicals in potato: A review. Food Res. Int., 50 (2), 487-496.

Evaluation of Certain Food Additives and Naturally Occurring Toxicants (1992). In: $39^{\text {th }}$ Report of the Joint FAO/WHO Expert Committee on Food Additives. WHO Technical Report Series 828. Geneva, pp. 31-33.

Friedman, M., Levin, C. E. (2009). Analysis and biological activities of potato glycoalkaloids, calystegine alkaloids, phenolic compounds and anthocyanins. In: Singh, J., Kaur, L. (eds). Advances in Potato Chemistry and Technology. Academic Press, pp. 127-161.

Hellenas, K. E., Nyman, A., Slanina, P., Loof, L., Gabrielsson, J. (1992). Determination of potato glycoalkaloids and their aglycone in blood serum by high-performance liquid chromatography: Application to pharmacokinetic studies in humans. J. Chromatogr. Biomed. Appl., 573, 69-78.

Im, H. W., Suh, B. S., Lee, S. U., Kozukue, N., Ohnisi-Kameyama, M., Levin, C. E., Friedman, M. (2008). Analysis of phenolic compounds by high-performance liquid chromatography and liquid chromatography/mass spectrometry in potato plant flowers, leaves, stems, and tubers and in home-processed potatoes. J. Agricult. Food Chem., 56 (9), 3341-3349.

Jansky, S. H. (2010). Potato flavor. Amer. J. Potato Res., 87 (2), 209-217.

Karim, M. S., Percival, G. C., Dixon, G. R. (1997). Comparative composition of aerial and subterranean potato tubers (Solanum tuberosum L). J. Sci. Food Agricult., 75, 251-257.

Kazeem, M. I., Akanji, M. A., Hafizur, R. M., Choudhary, M. I. (2012) Antiglycation, antioxidant and toxicological potential of polyphenol extracts of alligator pepper, ginger and nutmeg from Nigeria. Asian Pacific J. Tropical Biomed., 2 (9), 727-732.

Konate, K., Hilou, A., Mavoungou, J. F., Lepengue, A. N., Souza, A., Barro, N., Datte, J. Y., M'Batchi, B., Nacoulma, O. G. (2012). Antimicrobial activity of polyphenol-rich fractions from Sida alba L. (Malvaceae) against cotrimoxazol-resistant bacteria strains. Ann. Clin. Microbiol. Antimicrob., 11 (1), 1-6.

Kumar, Y., Yadav, D. N., Ahmad, T., Narsaiah, K. (2015). Recent trends in the use of natural antioxidants for meat and meat products. Comprehens. Rev. Food Sci. Food Safety, 14, 796-812.

Langkildea, S., Mandimika, T., Schrøder, M., Meyer, O., Slob, W., Peijnenburg, A., Poulsen, M. (2009). A 28-day repeat dose toxicity study of steroidal glycoalkaloids, $\alpha$-solanine and $\alpha$-chaconine in the Syrian Golden hamster. Food Chem. Toxicol., 47, 1089-1098.

Lei, C., Ma, Q., Tang, Q. Y., Ai, X. R., Zhou, Z., Yao, L., Wang, Y., Wang, Q., Dong, J. Z. (2014). Sodium selenite regulates phenolics accumulation and tuber development of purple potatoes. Scientia Horticult., 165, 142-147. 
Leo, L., Leone, A., Longo, C., Lombardi, D. A., Raimo, F., Zacheo, G. (2008). Antioxidant compounds and antioxidant activity in early potatoes. J. Agricult. Food Chem., 56 (11), 4154-4163.

Lewis, C. E, Walker, J. R. L., Lancaster, J. E., Sutton, K. H. (1998). Determination of anthocyanins, flavonoids and phenolic acids in potatoes. I: Coloured cultivars of Solanum tuberosum L. J. Sci. Food Agricult., 77 (1), 45-57.

Lewis, C. E., Walker, J. R. L., Lancaster, J. E. (1999). Changes in anthocyanin, flavonoid and phenolic acid concentrations during development and storage of coloured potato (Solanum tuberosum L.) tubers. J. Sci. Food Agricult., 79 (2), 311-316.

Lewis, C. E ., Walker, J. R. L., Lancaster, J. E., Conner, A. J. (1998). Light regulation of anthocyanin, flavonoid and phenolic acid biosynthesis in potato minitubers in vitro. Funct. Plant Biol., 25 (8), 915-922.

Machado, R., Toledo, M. C. F., Garcia, L. C. (2007). Effect of light and temperature on the formation of glycoalkaloids in potato tubers. Food Control, 18 (5), 503-508.

Manach, C., Scalbert, A., Morand, C., Remesy, C., Jimenez, L. (2004). Polyphenols: Food sources and bioavailability. Amer. J. Clin. Nutr., 79 (5), $727-747$.

Nara, K., Miyoshi, T., Honma, T., Koga, H. (2006). Antioxidative activity of bound form phenolics in potato peel. Biosci. Biotechnol. Biochem., 70 (6), 1489-1491.

Received 22 March 2021

Accepted in the final form 18 January 2022
Nascimento, L. B., Leal-Costa, M. V., Coutinho, M. A., Moreira, N. S., Lage, C. L., Barbi, N. S., Costa, S. S., Tavares, E. S. (2013). Increased antioxidant activity and changes in phenolic profile of Kalanchoe pinnata (Lamarck) Persoon (Crassulaceae) specimens grown under supplemental blue light. Photochem. Photobiol., 89 (2), 391-399.

Omayio, D. G., Abong, G. O., Okoth, M. W. (2016). A review of occurrence of glycoalkaloids in potato and potato products. Curr. Res. Nutr. Food Sci., 4 (3), 195-202.

Papathanasiou, F., Mitchell, S. H., Watson, S., Harvey, B. M. R. (1999). Effect of environmental stress during tuber development on accumulation of glycoalkaloids in potato (Solanum tuberosum L.). J. Sci. Food Agricult., 79, 1183-1189.

Puchau, B., Zulet, M. A., Echavarri, A. G., Hermsdorff, H. H. M., Martínez, J. A. (2010). Dietary total antioxidant capacity is negatively associated with some metabolic syndrome features in healthy young adults. Nutrition, 26 (5), 534-541.

Scalbert, A., Manach, C., Morand, C., Remesy, C., Jimenez, L. (2005). Dietary polyphenols and the prevention of diseases. Crit. Rev. Food Sci. Nutr., 45 (4), 287-306.

Singleton, V. L., Orthofer, R., Lamuela-Raventós, R. (1999). Analysis of total phenols and other oxidation substrates and antioxidants by means of Folin-Ciocalteu reagent. Methods Enzymol., 299, 152-178.

Skrabule, I., Grauda, D., Mikelsone, A., Vasariete, A. (2010). Adaptation of glycoalkaloids detection method for evaluation of Latvian potato genetic resources. Agron. Res., 8 (3), 705-710.

\section{UZGLABĀŠANAS APSTĀKḶU IETEKME UZ BIOAKTĪVAJĀM VIELĀM KARTUPEḶOS AR VIOLETU MĪKSTUMU}

Kartupeḷi (Solanum tuberosum L.) ir nozīmīgs dārzenis, kas dabiskā veidā satur augstas bioloǵiskās aktivitātes fenolu savienojumus. Stresa faktori var radīit auga aizsargreakciju, kuras rezultātā var samazināties fenolu savienojumu koncentrācija un vienlaicīgi palielināties glikoalkaloīdu (dabisko auga toksīnu) koncentrācija. Šì pētījuma mērḳis bija izvērtēt uzglabāšanas mākslīga apgaismojuma apstākḷos ietekmi uz bioaktīvajām vielām kartupeḷos ar violetu mīkstumu 'Blue Congo'. Eksperimentā tika izmantota šīs škirnes bumbuḷi, kas ievākti eksperimenta laukā Agroresursu un ekonomikas institūtā. Uzglabāšana septiņas dienas tika veikta mikroklimata uzturēšanas kamerā ICH1 10 (Memmert $\mathrm{GmbH}+\mathrm{Co} . K G$, Vācija) ar iestatītu un nemain̄̄gu gaisa relatīvo mitrumu $85 \%$, temperatūru $+22{ }^{\circ} \mathrm{C}$, pilna spektra 2000 luksu apgaismojumā (Eecoo, 1200 vati, LED). Kopējā fenolu koncentrācija, antioksidatīiā aktivitāte un kopējā glikoalkaloīdu koncentrācija tika noteikta ar spektrofotometrisko metodi, savukārt mitrums tika noteikts atbilstoši standartam LVS 272:2000. Šis pētījums pierādīja, ka violetās šķirnes ‘Blue Congo' kartupeḷu uzglabāšana mākslīgā apgaismojuma apstākḷos samazina kartupeḷos kopējo fenolu koncentrāciju un antioksidatīvo aktivitāti, mitruma līmenis nemainās, savukārt kopējā glikoalkaloīdu koncentrācija pieaug. 